\title{
Cellular Immune Response of Fetuses to Cytomegalovirus
}

\author{
MOHAMED ABDELHAYE ELBOU OULD, DOMINIQUE LUTON, MOUNIA YADINI, \\ BÉATRICE PEDRON, YANNICK AUJARD, EVELYNE JACQZ-AIGRAIN, \\ FRANÇOIS JACQUEMARD, AND GHISLAINE STERKERS \\ Laboratory of Immunology [M.A.E.O., M.Y., B.P., G.S.] and Departments of Maternity [D.L.], \\ Neonatology [Y.A.], and Pharmacology [E.J.-A.], Hôpital Robert Debré, 75019 Paris, France; and Institut \\ de Puericulture [F.J.], Boulevard Brune, 75019 Paris, France
}

\begin{abstract}
Primary infection with cytomegalovirus (CMV) in immunocompetent hosts is accompanied with activation and differentiation of naive $\mathrm{CD}^{+} \mathrm{T}$ cells to effector/memory cells secreting interferon- $\gamma(\mathrm{IFN}-\gamma)$. Alteration of these responses during the perinatal period is suggested by a higher rate of CMV diseases in congenital infection. For addressing this issue, immunologic investigations were performed in 15 fetuses (22-36 wk of gestation) with documented congenital CMV infection. Results show that cellular immune responses can be detected as soon as the 22nd week of gestation (the youngest fetus analyzed). Compared with age-matched control subjects, infected fetuses evidence a dramatic increase in the percentages of activated and terminally differentiated CD8 T cells. Indeed, median percentages (interquartile range) of $\mathrm{HLA}_{-} \mathrm{DR}^{+}$and of $\mathrm{CD} 28^{-} \mathrm{CD}^{+} \mathrm{T}$ cells were $24 \%(19-34)$ and $38 \%(24-52)$, respectively in infected fetuses versus 3\% (0-4) for each subset in control subjects. In addition, the percentages of T cells secreting IFN- $\gamma$ after in vitro stimulation with phorbol myristate acetate and
\end{abstract}

\section{ABSTRACT}

ionomycin was significantly higher in infected fetuses $[10 \%$ $(5-25)]$ than in healthy fetuses $[0.8 \%(0.6-1.2)]$ with IFN- $\gamma$ being mostly secreted by $\mathrm{CD} 8^{+} \mathrm{T}$ cells and to a lesser extend by $\mathrm{CD}^{+} \mathrm{T}$ cells. These cellular immune responses have clear similarities with responses previously reported in adults. Cellular immunity to CMV, however, might not be fully functional in fetuses. Indeed, the number of T cells capable of secreting IFN- $\gamma$ is strikingly lower after in vitro stimulation with the CMVspecific antigen than after in vitro stimulation with phorbol myristate acetate/ionomycin that bypasses signaling through the T-cell receptor. (Pediatr Res 55: 280-286, 2004)

CMV, cytomegalovirus

\section{Abbreviations}

IFN- $\boldsymbol{\gamma}$, interferon- $\gamma$

PMA, phorbol myristate acetate

$\mathrm{Ca}^{2+}$, ionomycin

PBMC, peripheral-blood mononuclear cells
$\mathrm{CD} 8^{+} \mathrm{T}$ lymphocytes are believed to be an important host defense against viruses. This concept is supported by the fact that patients with defects in cellular immunity experience more prolonged virus shedding and present more frequent and severe illness with cytomegalovirus (CMV) $(1,2)$. Furthermore, viral immunity to CMV can be restored by the adoptive transfer of $\mathrm{CMV}$-specific $\mathrm{CD}^{+}{ }^{+} \mathrm{T}$ cells in immunodeficient individuals (3).

During primary infection with $\mathrm{CMV}, \mathrm{CD} 8^{+} \mathrm{T}$ cells are activated, proliferate, and differentiate to become effector and memory lymphocytes. Effector/memory $\mathrm{CD} 8^{+} \mathrm{T}$ cells possess cytotoxic activity. In addition, they become capable of releasing factors with antiviral action, such as interferon- $\gamma($ IFN- $\gamma)$

Received January 20, 2003; accepted August 7, 2003.

Correspondence: Ghislaine Sterkers, Laboratoire d'Immunologie, Hôpital Robert Debré, 48 Boulevard Sérurier, 75019 Paris, France; e-mail: ghislaine. sterkers@rdb.ap-hop-paris.fr

DOI: 10.1203/01.PDR.0000104150.85437.FE
(4). Activation and differentiation of $\mathrm{CD} 8^{+} \mathrm{T}$ cells during viral infection are associated with changes in the cell surface phenotype. In persistent virus infections, HLA-DR expression on $\mathrm{CD}^{+} \mathrm{T}$ cells reflects immune activation (5). Also, during the course of infection, part of $\mathrm{CD} 8 \mathrm{~T}$ cells switch progressively to a long-lived $\mathrm{CD} 8^{+} \mathrm{CD} 28^{-}$T-cell pool (6), which contains virus-specific, cytolytic $\mathrm{T}$ lymphocytes $(7,8)$. It has been suggested that these $\mathrm{CD} 28^{-} \mathrm{CD} 8^{+} \mathrm{T}$ cells might be terminally differentiated because of their poor proliferative potential (9).

The great majority of primary CMV infections in immunocompetent hosts are clinically silent, whereas the rate of CMV disease is $10-15 \%$ in congenital infection (10). This difference is supposed to be related to the immaturity of the immune system. The concept of immaturity of $\mathrm{CD} 8^{+} \mathrm{T}$-cell functional responses to viruses has been largely documented in mouse models $(11,12)$ and also suggested in the human. As an example, the incidence of children who are younger than 6 mo of age and develop CD8 T-cell activities, as measured by cytotoxicity $(13,14)$ or IFN- $\gamma$ secretion (15) assays, is low 
compared with the one seen in adults. Also, cytolytic responses directed against the respiratory syncytial virus are more pronounced and more frequent in 6- to 24- than in 0- to 5-mo-old infants (16). There are few data about $\mathrm{CD}^{+} \mathrm{T}$-cell response to CMV in early gestational ages.

We explored cellular T-cell responses in fetuses with documented CMV infection. Our study primarily focused on the subset composition of the CD8 compartment and on the capacity of $\mathrm{CD}^{+}$cells to become IFN- $\gamma$ producer cells. Our results indicate that expansion of activated (HLA-DR ${ }^{+}$) and terminally differentiated $\left(\mathrm{CD} 28^{-}\right) \mathrm{CD}^{+} \mathrm{T}$ cells can be observed as soon as the 22nd week of gestation in fetuses infected with CMV. In addition, a consequent proportion of $\mathrm{CD}^{+} \mathrm{T}$ cells gain the capacity of producing IFN- $\gamma$ after in vitro exposure to the nonspecific and potent activators phorbol myristate acetate (PMA) and ionomycin $\left(\mathrm{Ca}^{2+}\right)$. The proportion of $\mathrm{T}$ cells secreting IFN- $\gamma$ after in vitro exposure to the specific CMV antigen was clearly lower. On the basis of these data, the competence of the immune system to fight CMV during the intrapartum period is discussed.

\section{METHODS}

Patients and control subjects. The study was approved by the local committee of the Robert Debré perinatal department. For blood sampling by cordocentesis after delivery or before pregnancy termination and for the use of residual bloods from fetuses, oral information was given to the parents without written consent. For blood sampling from adult control subjects, selectively performed for the purpose of the study, all individuals gave written informed consent. Fifteen fetuses were included. Prenatal diagnosis of CMV infection was achieved for 11 fetuses during evaluation of pregnancies with mothers' primary CMV infection within the first trimester. Documentation of CMV infection was based on CMV isolation on MRC5 monolayers and CMV DNA detection by PCR (Light Cycle; Roche Diagnostics, Meylan, France) done on amniotic fluid. Diagnosis was achieved at birth for four fetuses and from mothers with primary CMV infection during the first trimester of pregnancy but without any fetus evaluation during pregnancy. Documentation of CMV infection, at birth, was based on CMV-IgM antibody detection (ELISA; VIDAS CMV IgM; Biomérieux, Maray l'étoile, France) and/or viral shedding (CMV isolation on MRC5 monolayer). The mean age of gestation at the time of immunologic evaluation was $29 \mathrm{wk}$ (range, 22-38). In 11 cases, blood samples consisted of residual blood from cordocentesis dedicated to hematologic, biochemical, and/or virologic analysis in the fetus either during the pregnancy evaluation $(n=5)$ or during elective termination of pregnancy $(n=6)$. Of the six elective terminations of pregnancy, one was requested by the parents and five were performed because of ultrasound and/or biologic abnormalities. For four fetuses, cordocentesis was performed at birth of the neonate immediately after delivery.

Controls consisted of cord blood from full-term $(38-40 \mathrm{wk}$ of gestation) uncomplicated pregnancies $(n=11)$ and from elective pregnancy termination for fetal malformation $(n=43$;
17-38 wk of gestation). We also used, in some assays (Fig. 1), blood from adult volunteer donors $(n=10)$ as controls.

Blood samples were collected on EDTA (immunophenotyping assays) and on acid citrate dextrose (IFN- $\gamma$ expression assays) to prevent coagulation. All tests were performed on the day of sampling.

Immunophenotyping. Direct immunofluorescence staining was performed on whole blood using a combination of two (CD4/CD45R0), three (CD3/CD8/HLA-DR, CD3/CD8/CD28, CD3/CD8/CD45RA, CD4/CD45RA/CD621), or four (CD3/ CD4/CD8/CD45, CD3/CD19/CD16+CD56/CD45) directly labeled MAb. MAb were purchased from 1) Becton-Dickinson, le Pont de Claix, France (CD4-FITC, CD45RO-PE, HLA-DRPE, CD28-PE, CD62 L-FITC, and also CD3-FITC/CD4-APC/ CD8-PE/CD45-per-CP and CD3-FITC/CD19-APC/ CD16+CD56-PE/CD45-Per-CP combinations), 2) Immunotech, Marseille, France (CD3-FITC), and 3) Coulter, Miami, Florida, U.S.A. (CD8 ${ }^{-}$PECy5). In brief, $100 \mu \mathrm{L}$ of whole blood was added to a premixed solution of MAb at the appropriate dilution. After a 15-min incubation at room temperature in the dark, red blood cells were lysed by using FACS Lysing (Becton-Dickinson, Le Pont declai, France). Samples were washed twice and resuspended in PBS. Analysis was performed in a FACScalibur (Becton-Dickinson) instrument with the Cellquest software. For each sample, peripheral-blood mononuclear cells (PBMC) were gated into the lymphocyte population according to forward and side scatter characteristics, and 10,000 events were acquired in this gate. The absolute number of lymphocytes B, T, CD4, CD8, and NK cells was determined by using counting beads in the multitest (CD3/ CD4/CD8/CD45 and CD3/CD19/CD16+CD56/CD45) flowcytometry assays and according to the manufacturer recommendations (Becton-Dickinson).

IFN- $\boldsymbol{\gamma}$ expression. PBMC were isolated by differential centrifugation over "lymphocytes separation medium" (Eurobio, Les Ulis, France), and $10^{6}$ cells $/ \mathrm{mL}$ were resuspended in complete RPMI medium 1640 (Eurobio) supplemented with penicillin/streptomycin/L-glutamine and 10\% FCS (Valbiothech, Paris, France) in culture tubes (1 mL/tube). PBMC were stimulated with ionomycin, $500 \mathrm{ng} / \mathrm{mL}$ (Calbiochem-MerckEurolab, Fontenay sous Bois, France), and PMA $50 \mathrm{ng} / \mathrm{mL}$ (ICN Biomedicals, Orsay, France) or a CMV antigen preparation from a commercially prepared lysate of CMV-infected fibroblasts at $10 \mathrm{ng} / \mathrm{mL}$ (complement fixation reagent; Bio Whittaker, Verviers, Belgium). Cells without stimulator were cultured in parallel to be used as negative control. Brefeldin A, $15 \mu \mathrm{g} / \mathrm{mL}$ (ICN Biomedicals) was added, since the second hour of culture in all tubes for intracellular accumulation of the secreted proteins. Cultures were incubated for $18 \mathrm{~h}$ at $37^{\circ} \mathrm{C}$ in a humidified $\mathrm{CO}_{2}$ incubator before intracellular staining. After an initial wash in FACS-Flow (Becton-Dickinson), stimulated and unstimulated (negative control) cells were fixed and permeabilized according to the manufacturer recommendations (DAKO intrastain; Glostrup, Denmark). Cells were then stained with CD3-FITC (Immunotech), CD8-PECy5 (Immunotech), and anti-IFN- $\gamma$-PE (Becton-Dickinson) MAb for 20 min at room temperature in the dark. Cells were then washed twice and analyzed in a FACScalibur (Becton-Dickinson) in- 
CMV- infected fetuses

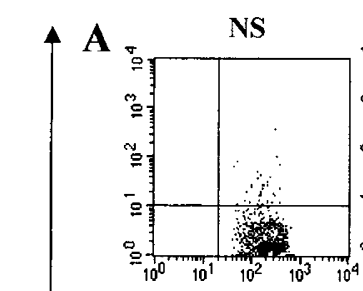

\begin{tabular}{c|c}
$\mathbf{I}$ & $\mathbf{F}$ \\
$\mathbf{N}$ & \\
$\gamma$ &
\end{tabular}

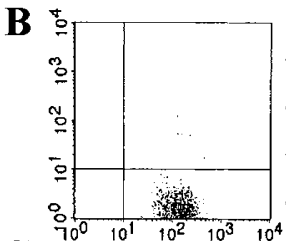

C
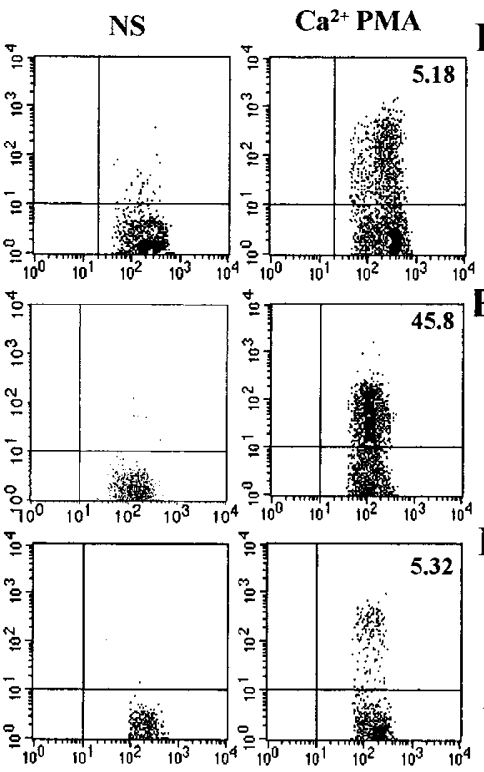

Healthy neonates
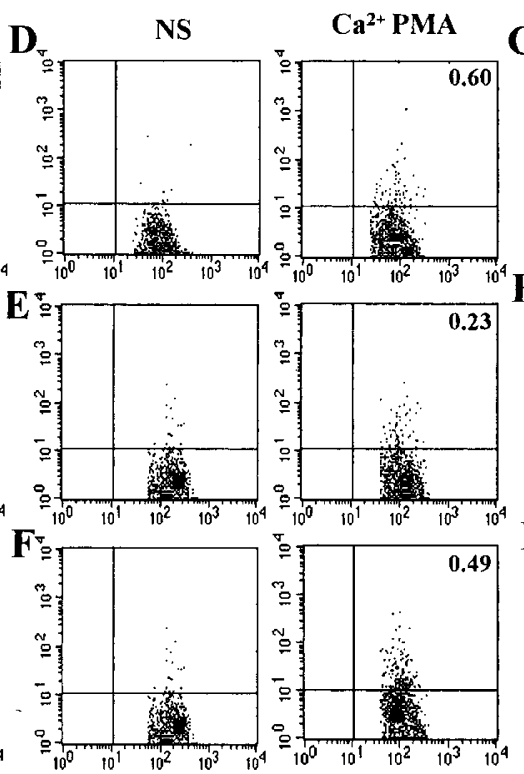

\section{Healthy adults}

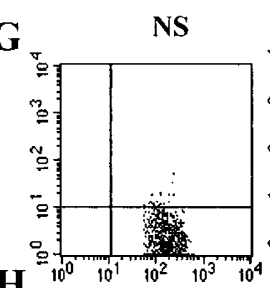

$\mathrm{Ca}^{2+}$ PMA
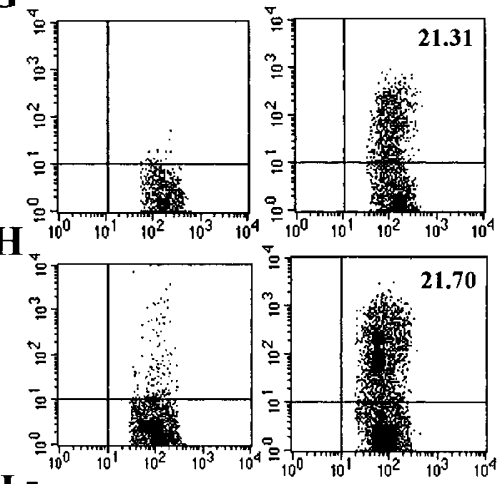

1

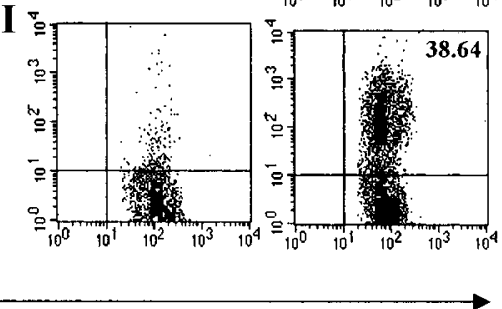

CD3

Figure 1. IFN- $\gamma$ responses to $\mathrm{Ca}^{2+} / \mathrm{PMA}$ by $\mathrm{T}$ cells from $\mathrm{CMV}$-infected fetuses, healthy neonates, and healthy adults. After stimulation of PBMC with the nonspecific activator $\mathrm{Ca}^{2+} / \mathrm{PMA}$, cells were permeabilized and stained with MAb specific for IFN- $\gamma$, CD3, and CD8. We analyzed the frequency of IFN- $\gamma$-producing T cells by sequential gating on the lymphocyte population and then on CD ${ }^{+}$lymphocytes as described in "Methods." The fraction of secreting T cells was then determined by calculating the ratio of cells expressing CD3 ( $x$ axis) and intracellular IFN- $\gamma\left(y\right.$ axis) over the total CD3 ${ }^{+}$cells $\times 100$. Percentages are given in the right upper quadrant. In all cases, percentages observed in nonstimulated culture (NS) are deduced. The results for three independent assays performed in three distinct fetuses infected with CMV and distinct controls are provided.

strument with the Cellquest software. Between 1 and $2.5 \times 10^{5}$ events were acquired depending on sample availability. Unstimulated control samples showed a low background staining that was subtracted in calculating the frequency of IFN- $\gamma$ producing cells. Staining with isotype control MAb was consistently negative. In all assays, we analyzed cells using a $\mathrm{CD}^{+}$cell gate, and we considered $\mathrm{CD} 8^{-}$cells within this gate as $\mathrm{CD} 4^{+} \mathrm{T}$ lymphocytes.

Statistical analysis. Statistical analysis used a nonparametric test (Mann-Whitney) for quantitative variable. $P<0.05$ was considered as significant.

\section{RESULTS}

Reference values for lymphocyte subsets in cord blood. At first, reference values for lymphocyte subsets were determined in a population of 54 control fetuses, from 17 to $40 \mathrm{wk}$ of gestation age, either healthy or with diseases that do not alter immune system development (see "Methods"). Results showed that fetal lymphocyte absolute values increase with time from 17 to $40 \mathrm{wk}$ of gestation, whereas percentages of lymphocyte subsets do not (data not shown). The medians found in the 54 fetuses (irrespective of their gestation age) therefore were used as reference values. As shown in Table 1, these reference values evidence a dominance of naive $\left(\mathrm{CD} 4 / \mathrm{RA}^{+}\right.$or $\mathrm{CD} 8 /$ $\left.\mathrm{CD} 45 \mathrm{RA}^{+}\right)$over memory $\left(\mathrm{CD} 4 / \mathrm{CD} 45 \mathrm{RO}^{+}\right.$or $\mathrm{CD} 8 /$ $\mathrm{CD} 4 \mathrm{RA}^{-}$cells). Very few $\mathrm{CD} 8^{+} \mathrm{T}$ cells express the activation marker HLA-DR (CD8/CD3/HLA-DR $\left.{ }^{+}\right)$. Moreover, the percentage of $\mathrm{CD}^{+} \mathrm{T}$ cells lacking the $\mathrm{CD} 28$ molecule (CD8/ $\left.\mathrm{CD} 3 / \mathrm{CD} 28^{-}\right)$is very low. This profile is characteristic of naive individuals who still have not experienced antigen. Of note, virtually all $\mathrm{CD} 4 / \mathrm{CD} 45 \mathrm{RA}^{+}$cells express the selectin CD62 L (data not shown).

Preferential expansion of $\mathrm{CDB}^{+} \mathrm{T}$ cells and increased proportion of memory $T$ cells in fetuses infected with $C M V$. The phenotype of circulating lymphocyte subsets was assessed in $15 \mathrm{CMV}$-infected fetuses (mean gestational age, $29 \mathrm{wk}$; range, $22-38 \mathrm{wk}$ ). The median of percentages found in CMVinfected fetuses was compared with the median of percentages found in the 54 control fetuses (mean gestational age, $29 \mathrm{wk}$; range, 17-40 wk). As shown in Table 1, there is no significant difference between the two groups in either total lymphocyte counts, or B lymphocyte percentages or natural killer cell percentages compared with reference values. By contrast, $\mathrm{CMV}$-infected fetuses have lower $\mathrm{CD}^{+}{ }^{+}$(both percentages and absolute counts) and higher $\mathrm{CD} 8^{+}$percentages (Table 1). In addition, a significant switch of naive $\left(\mathrm{CD} 45 \mathrm{RA}^{+}\right)$to memory $\left(\mathrm{CD} 45 \mathrm{RA}^{-}\right.$or $\mathrm{CD} 45 \mathrm{RO}^{+}$) phenotype is observed in patients. A significant proportion of naive $\mathrm{CD} 4 / \mathrm{CD}_{4} 5 \mathrm{RA}^{+}$cells have switched to the memory $\mathrm{CD} 4 / \mathrm{CD} 45 \mathrm{RO}^{+}$phenotype. The percentage of $\mathrm{CD}^{+}$naive cells $\left(\mathrm{CD} 3 / \mathrm{CD} 8 / \mathrm{CD} 45 \mathrm{RA}^{+}\right)$, decreased and the percentage of $\mathrm{CD}^{+}$memory cells $(\mathrm{CD} 3 / \mathrm{CD} 8 /$ $\mathrm{CD} 4 \mathrm{RA}^{-}$) increased. Of note, the CD62L molecule remained expressed on the great majority of CD4/CD45RA ${ }^{+}$cells (data not shown). Thus, CMV infection is associated with a prefer- 
Table 1. Lymphocyte subpopulations in CMV-infected fetuses

\begin{tabular}{|c|c|c|c|}
\hline Cell type & $\begin{array}{c}\text { CMV-infected } \\
\text { fetuses } \\
(n=15)\end{array}$ & $\begin{array}{l}\text { Reference } \\
\text { values } \\
(n=54)\end{array}$ & $p$ values \\
\hline Total lymphocytes $\left(10^{-9} / \mathrm{L}\right)^{*}$ & $2.7[2.3-4.4]$ & $2.7[1.8-4]$ & NS \\
\hline B lymphocytes $(\%) \dagger$ & $28[14-40]^{*}$ & $19[14-27]$ & NS \\
\hline NK cells $(\%) \dagger$ & $06[04-13]$ & $07[04-12]$ & NS \\
\hline $\mathrm{T}$ lymphocytes $(\%) \dagger$ & $58[48-62]$ & $68[60-75]$ & 0.0004 \\
\hline CD4 $(\%)$ & $34[25-40]$ & $49[42-54]$ & 0.0009 \\
\hline$\left(10^{-9} / \mathrm{L}\right)$ & $0.95[0.67-1.22]$ & $1.33[0.89-1.7]$ & 0.047 \\
\hline CD8 (\%) & $24[18-30]$ & $20[16-23]$ & 0.044 \\
\hline$\left(10^{-9} / \mathrm{L}\right)$ & $0.58[0.45-1.3]$ & $0.46[0.37-0.71]$ & NS \\
\hline \multicolumn{4}{|l|}{ Naive/memory cells (\%) } \\
\hline $\mathrm{CD} 4 / \mathrm{CD} 45 \mathrm{RA}^{+}$in $\mathrm{CD} 4$ & $85[66-90] \ddagger$ & $94[90-96]$ & 0.01 \\
\hline $\mathrm{CD} 4 / \mathrm{CD} 45 \mathrm{RO}^{+}$in CD4 & $11[10-20] \leftrightarrows$ & $07[05-09]$ & 0.004 \\
\hline $\mathrm{CD} 3 / \mathrm{CD} 8 / \mathrm{CD} 45 \mathrm{RA}^{+}$in $\mathrm{CD} 8$ & $92[69-94] \ddagger$ & $95[92-97]$ & 0.026 \\
\hline $\mathrm{CD} 3 / \mathrm{CD} 8 / \mathrm{CD} 45 \mathrm{RA}^{-}$in $\mathrm{CD} 8$ & $08[06-31] \ddagger$ & $05[03-08]$ & 0.01 \\
\hline \multicolumn{4}{|l|}{ Activated/effector CD8 (\%) } \\
\hline $\mathrm{CD} 3 / \mathrm{CD} 8 / \mathrm{HLA}-\mathrm{DR}^{+}$in CD8 & $24[19-34]$ & $03[00-04]$ & $<0.0001$ \\
\hline $\mathrm{CD} 3 / \mathrm{CD} 8 / \mathrm{CD} 28^{-}$in $\mathrm{CD} 8$ & $38[25-52]$ & $03[00-04]$ & $<0.0001$ \\
\hline
\end{tabular}

* Results are given as median [interquartile range].

$\dagger$ B lymphocytes are $\mathrm{CD} 19^{+}$cells; T lymphocytes are $\mathrm{CD}^{+}$cells; and $\mathrm{NK}$ are $\mathrm{CD} 16^{+} / \mathrm{CD} 56^{+} / \mathrm{CD} 3^{-}$cells. $P>0.05$ is considered nonsignificant $(\mathrm{NS})$. Statistical analysis used a nonparametric test (Mann-Whitney).

$\ddagger$ Seven to 12 instead of 15 infected fetuses were analyzed.

ential expansion of the $\mathrm{CD} 8^{+}$over the $\mathrm{CD} 4^{+} \mathrm{T}$-cell compartment, and a switch of naive to memory $\mathrm{T}$ cells has been noticed.

Signs of immune activation and accumulation of terminally differentiated $\mathrm{CDS}^{+} \mathrm{T}$ cells in fetuses infected with $\boldsymbol{C M V}$. When comparing the CD8 subsets between CMVinfected fetuses and reference values, activated (HLA-DR ${ }^{+}$) and terminally differentiated $\left(\mathrm{CD} 28^{-}\right) \mathrm{CD}^{+} \mathrm{T}$ cells differed strikingly between the two groups (Table 1). The percentage of activated $\mathrm{CD} 8^{+} \mathrm{T}$ cells within the $\mathrm{CD} 8^{+} \mathrm{T}$-cell compartment $\left(\mathrm{CD} 3 / \mathrm{CD} 8 / \mathrm{HLA}_{-} \mathrm{DR}^{+}\right.$in CD8) increased significantly in patients. Also, a huge increase of the $\mathrm{CD} 8 / \mathrm{CD} 3 / \mathrm{CD} 28^{-}$subset within the $\mathrm{CD}^{+} \mathrm{T}$ cell compartment was observed.

Because all fetuses who were infected with CMV were from mothers with documented primary infection during pregnancy, we controlled that accumulation of activated $\left(\mathrm{HLA}-\mathrm{DR}^{+}\right)$and terminally differentiated $\left(\mathrm{CD} 28^{-}\right) \mathrm{CD}^{+} \mathrm{T}$ cells found in CMV-infected fetuses is not related to the virologic status of the mother. This was achieved by testing blood samples of neonates who were born to mothers with primary infection during pregnancy but who themselves were not infected. As expected, no change in the percentages of activated and terminally differentiated $\mathrm{CD} 8^{+} \mathrm{T}$ cells was observed in fetuses when the virus was not transmitted (data not shown).

Quantification of cells producing IFN- $\gamma$ after stimulation by $\boldsymbol{C a}^{2+} / \boldsymbol{P M A}$. A cytometry assay was used to quantify $\mathrm{T}$ cells $\left(\mathrm{CD}^{+}\right)$capable of producing IFN- $\gamma$ in response to the nonspecific $\mathrm{Ca}^{2+} /$ PMA polyclonal activator. It is well known that $\mathrm{T}$ cells fail to produce IFN- $\gamma$ unless they have been primed in vivo by antigen. We therefore used in each assay two control populations. Cord blood from healthy neonates, that have encountered few if any antigens, were used as low-producer control subjects, and blood from healthy adults, that have been primed by numerous antigens, were used as high-producer control subjects. Results from three distinct fetuses compared with three distinct adults and three distinct healthy neonates are shown in Figure 1. They clearly show that poor IFN- $\gamma$ production by $\mathrm{T}$ cells from healthy neonates contrasts with significant IFN- $\gamma$ secretion by CMV-infected fetuses and healthy adults. In total, six CMV-infected fetuses were analyzed. The median level of IFN- $\gamma$ response in the infected population $[10 \%(5-$ $25)]$ was significantly higher $(p=0.001)$ than in the 10 naive healthy neonates whom we analyzed $[0.8 \%(0.6-1.2)]$. Using three-color (CD3/CD8/anti-IFN- $\gamma$ ) cytometry assays, it is possible to determine which $\mathrm{CD}^{+}$or $\mathrm{CD} 8^{-}$(i.e. $\mathrm{CD} 4^{+}$) subset among $\mathrm{CD}^{+}{ }^{+} \mathrm{T}$ cells is capable of secreting IFN- $\gamma$. As illustrated for three distinct fetuses in Figure 2, a higher proportion of $\mathrm{CD}^{+} \mathrm{T}$ cells than $\mathrm{CD} 8^{-} \mathrm{T}$ cells $(27.5-67.5 \%$ versus 4.9-7.9\%) were capable of secreting IFN- $\gamma$ in CMV-infected fetuses.

Quantification of cells producing IFN- $\gamma$ after stimulation with the CMV antigen. The feasibility of detecting and quantifying IFN- $\gamma$ responses to CMV antigen was demonstrated by comparing responses in peripheral blood from healthy adults exposed to the virus (people from our staff) with responses in a naive population of healthy neonates (cord blood). Among 10 subjects who were exposed to the virus, the mean frequency of $\mathrm{T}$ cells producing IFN- $\gamma$ after stimulation with the CMV antigen was $0.17 \%$, whereas among 10 neonates, the mean CMV antigen-specific effector frequency for this cytokine was at background $(-0.03 \%)$. Using the same method, IFN- $\gamma$ responses to $\mathrm{CMV}$ by $\mathrm{CD}^{+} \mathrm{T}$ cells could also be detected in adults because the mean frequency of $\mathrm{CD}^{+} \mathrm{T}$ cells producing IFN- $\gamma$ was $0.11 \%$ in the 10 adults versus at background $(-0.07 \%)$ in the 10 neonates. On the basis of these preliminary data, we numerated $\mathrm{T}$ cells secreting IFN- $\gamma$ after stimulation with the specific viral antigen in four fetuses infected with CMV. Consistent IFN- $\gamma$ response by T cells to the nonspecific $\mathrm{Ca}^{2+} /$ PMA activator in these four fetuses (mean, $8 \%$; range, $4.8-11.14 \%$ ) contrasted with strikingly lower (and even unde- 


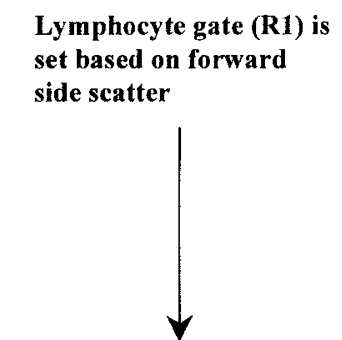

Secondary gate is set on $\mathrm{CD3}^{+}$cells (R2)

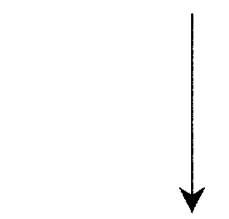

IFN-gamma response to $\mathrm{Ca}^{2+} \mathrm{PMA}$ within $\mathrm{CD8}^{-}$(left) and $\mathrm{CD8}^{+}$ (right) $\mathrm{CD3}^{+}$cells (R2)
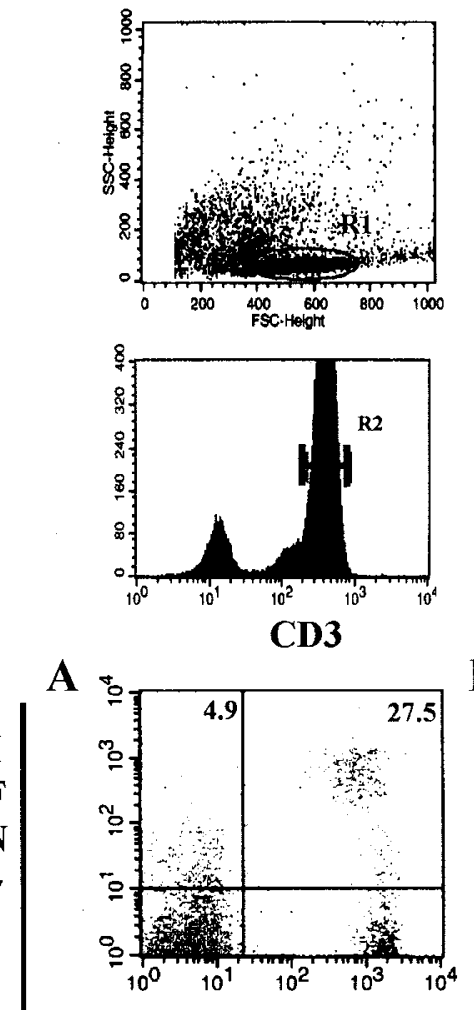

B

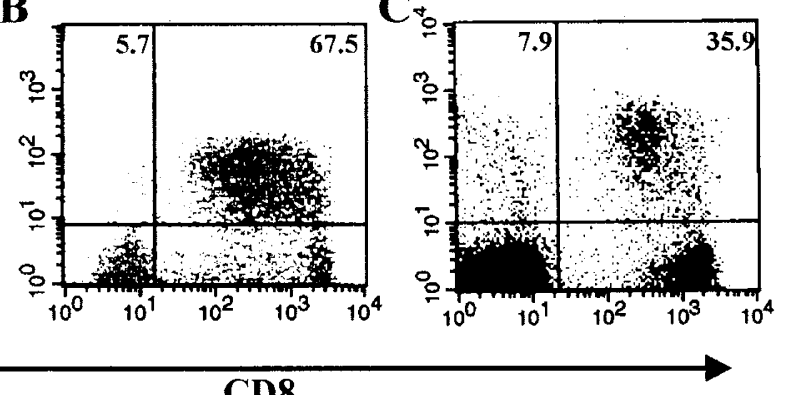

Figure 2. Frequencies of IFN- $\gamma$-secreting cells among $\mathrm{CD}^{+}$and $\mathrm{CD} 8^{-}$(i.e. CD4) $\mathrm{T}$ cells after stimulation with $\mathrm{Ca}^{2+} / \mathrm{PMA}^{2}$ After stimulation as in Figure 1 , lymphocyte gate R1 is set based on lymphocyte forward and side scatter characteristics. Then a secondary gate (R2) is set on CD3 ${ }^{+}$cells. The frequencies of IFN- $\gamma$-secreting cells among CD8 ${ }^{-}$(upper left signals/upper + lower left signals $\times 100$ ) and among $\mathrm{CD}^{+}$cells (upper right signals/upper + lower right signals $\times 100)$ are given in the upper quadrants. The results for three independent assays performed in three distinct fetuses infected with CMV are provided.

tectable in some patients) T-cell responses to the CMV antigen (mean, $0.6 \%$; range, $-0.01 \%$ to $1.84 \%$ ).

\section{DISCUSSION}

We have documented the CD8 T-cell immune response in congenital human CMV infection. In addition to a switch of a proportion of circulating $\mathrm{T}$ cells from a naïve $\left(\mathrm{CD} 45 \mathrm{RA}^{+}\right)$to a memory $\left(\mathrm{CD}^{2} 5 \mathrm{RA}^{-}\right)$state, immunophenotyping assays revealed a gain of HLA-DR and a loss of CD28 expression on $\mathrm{CD}^{+} \mathrm{T}$ cells in infected fetuses as soon as the 22 nd week of gestational age (the youngest fetus analyzed). Increased expression of HLA-DR (5) and loss of CD28 (personal observation) has been previously found in neonates infected with HIV and also in neonates with congenital Trypanosoma cruzi infection (17). Therefore, the activation and differentiation to terminally differentiated phenotypes of $\mathrm{CD} 8^{+} \mathrm{T}$ cells could occur very early after birth (HIV) or even before birth (Trypanosoma). In vivo exposure of fetuses to CMV leads to accumulation of activated and terminally differentiated $\mathrm{CD} 8^{+} \mathrm{T}$ cells as soon as the $22 \mathrm{nd}$ week of gestation or even before. These phenotypic changes mimic those previously described in adults during primary infection with viruses. It is interesting that these changes have been associated with the clearance of herpes viridae viruses from the blood and with the development of protective immunity in adults (17).
The induction of CD8 T-cell functional responses to viruses is age-dependent and much weaker in early age than in adults (13-16). Among $\mathrm{CD}^{+} \mathrm{T}$ cells, those that produce IFN- $\gamma$ are believed to play an important role in the control of $\mathrm{CMV}$ replication. Our results show that CMV infection in fetuses increases considerably the frequency of $\mathrm{CD}^{+} \mathrm{T}$ cells producing IFN- $\gamma$ after stimulation with $\mathrm{Ca}^{2+} / \mathrm{PMA}$. This indicates that these cells are endowed with an effector machinery. Significantly fewer cells produced IFN- $\gamma$ after specific stimulation with the CMV antigen. This difference did not result from inefficient generation of HLA class I or HLA class II peptides from CMV antigen because the antigenic preparation that was used in this study was previously shown to induce IFN- $\gamma$ responses by both CD4 and CD8 T cells in $\mathrm{CMV}^{+}$adults (18). Furthermore, we have demonstrated that $\mathrm{CMV}$-induced cytokine production by $\mathrm{CD}^{+}$or $\mathrm{CD} 8^{+} \mathrm{T}$ cells in our flow cytometric assay correlates with exposure to the CMV antigen. Three nonexclusive mechanisms can be evoked to explain this dissociation. First, in congenital CMV infection, most IFN- $\gamma$ secreting cells might not be specific for the CMV antigen. Recently, a new technique using HLA class I peptide tetrameric complexes has been developed for enumerating antigen-specific $\mathrm{CD}^{+} \mathrm{T}$ cells (19). One general observation using this method has been that the massive expansion of $\mathrm{CD} 8^{+} \mathrm{T}$ cells during acute viral infections is indeed caused by antigen- 
specific $\mathrm{T}$ cells and cannot be explained by bystander activation $(20,21)$. Although enumeration of $\mathrm{CD} 8^{+} \mathrm{T}$ lymphocytes was not feasible in fetuses for technical reasons (small size of blood samples), the possibility that the great majority of memory $\mathrm{CD}^{+} \mathrm{T}$ cells are not virus-specific selectively in congenital CMV infection seems unlikely. A second hypothesis is a stimulation by the specific antigen in vitro suboptimal to detect IFN- $\gamma$ secretion in fetuses. There is no universal stimulation protocol to detect IFN- $\gamma$-producing cells. Some studies used extensive co-stimulation $(18,22)$. We chose to limit T-cell stimulation to presentation of antigen without co-stimulation because subtle defects in T-cell responsiveness may be masked when the stimulation is too strong. Finally, the last hypothesis, which is the one that we favor, is that CMV-specific T lymphocytes are not fully functional in fetuses. In line with this interpretation, an increased number of studies concluded to impaired function of $\mathrm{CD} 8^{+} \mathrm{T}$ cells based on data showing a dissociation between the number of $\mathrm{CD}^{+} \mathrm{T}$ cells primed with viruses and the number of $\mathrm{T}$ cells that respond to the corresponding viral antigens by IFN- $\gamma$ production (23-26). Comparing IFN- $\gamma$ responses with CMV during primary infection in both fetuses and adults should definitely demonstrate whether CD8 response to CMV is less intense in early age. Unfortunately, this is complicated given the difficulties of studying clinically silent primary infections in adults.

In addition to $\mathrm{CD} 8^{+} \mathrm{T}$ cells, $\mathrm{CD} 4^{+} \mathrm{T}$ cells are required for control of viral infections. They contribute to viral clearance through a variety of mechanisms, including help for $\mathrm{CD} 8^{+} \mathrm{T}$ cells $(27,28)$. Although the CD8 T-cell response predominates in CMV-infected fetuses, we also detected, to a lesser extent, CD4 T-cell responses. They include a shift of a proportion of $\mathrm{CD}^{+} \mathrm{T}$ cells to a memory phenotype and also a priming to produce IFN- $\gamma$ after $\mathrm{Ca}^{2+} / \mathrm{PMA}$ stimulation. Although present, these responses might be quantitatively insufficient to promote vigorous CD8 T-cell responses. This scenario is suggested by previous reports that have indicated poor T-cell proliferative responses to the CMV antigen in neonates infected with CMV (29, 30). In addition, decreased CD4 T-cell count during congenital infection (this article) might contribute in shortening $\mathrm{CD}^{+}{ }^{+} \mathrm{T}$-cell response.

\section{CONCLUSION}

In conclusion, our results provide new data in the delineation of CD8 T-cell responses in congenital CMV infection. They indicate that expansion of $\mathrm{CD} 8 \mathrm{~T}$ cells endowed to secrete IFN- $\gamma$ occurs since $22 \mathrm{wk}$ of gestation in response to CMV infection. These results do not exclude, however, that cytokine production in vivo in response to the specific viral antigen can be less vigorous in fetuses than in more mature individuals.

Acknowledgment. The cooperation of all patients and control subjects is gratefully acknowledged. We thank Christophe Merlette, Catherine Martinet, and Valérie Broc for excellent technical assistance; Sandie Samb and Nadine Battery for typing the manuscript; and Corine Alberti for advice regarding statistical analysis.

\section{REFERENCES}

1. Reusser P, Attenhofer R, Hebart H, Helg C, Chapuis B, Einsele H 1997 Cytomegalovirus-specific T-cell immunity in recipients of autologous peripheral blood stem cell or bone marrow transplants. Blood 89:3873-3879

2. Schrier RD, Freeman WR, Wiley CA, McCutchan JA 1995 Immune predispositions for cytomegalovirus retinitis in AIDS. The HNRC Group. J Clin Invest 95:1741-1746

3. Riddell SR, Watanabe KS, Goodrich JM, Li CR, Agha ME, Greenberg PD 1992 Restoration of viral immunity in immunodeficient humans by the adoptive transfer of T-cells clones. Science 257:238-241

4. Hamann D, Baars PA, Rep MH, Hooibrink B, Kerkhof-Garde SR, Klein MR, van Lier RA 1997 Phenotypic and functional separation of memory and effector human CD8 ${ }^{+}$ T cells. J Exp Med 186:1407-1418

5. Rich KC, Chang BH, Mofenson L, Fowler MG, Cooper E, Pitt J, Hillyer GV, Mendez H 1997 Elevated CD8 ${ }^{+}$DR $^{+}$lymphocytes in HIV-exposed infants with early positive HIV cultures: a possible early marker of intrauterine transmission. Women and Infants Transmission Study Group. J Acquir Immune Defic Syndr Hum Retrovirol $15: 204-210$

6. Hamann D, Roos MT, van Lier RA 1999 Faces and phases of human CD8 ${ }^{+}$T-cell development. Immunol Today 20:177-180

7. Appay V, Dunbar PR, Callan M, Klenerman P, Gillespie GM, Papagno L, Ogg GS, King A, Lechner F, Spina CA, Little S, Havlir DV, Richman DD, Gruener N, Pape G, Waters A, Easterbrook P, Salio M, Cerundolo V, McMichael AJ, Rowland-Jones SL 2002 Memory CD8 ${ }^{+} \mathrm{T}$ cells vary in differentiation phenotype in different persistent virus infections. Nat Med 8:379-385

8. Weekes MP, Carmichael AJ, Wills MR, Mynard K, Sissons JG 1999 Human CD28$\mathrm{CD}^{+} \mathrm{T}$ cells contain greatly expanded functional virus-specific memory CTL clones. J Immunol 162:7569-7577

9. Vingerhoets JH, Vanham GL, Kestens LL, Penne GG, Colebunders RL 1995 Increased cytolytic T lymphocyte activity and decreased B7 responsiveness are associated with CD28 down-regulation on CD8 + T-cells from HIV infected subjects. Clin Exp Immunol 100:425-433

10. Stagno S, Whitley RJ 1985 Herpes virus infection of pregnancy. N Engl J Med 313:1270-1274

11. Siegrist CA, Saddallah F, Tougne C, Martinez X, Kovarik J, Lambert PH 1998 Induction of neonatal TH1 and CTL responses by live viral vaccines: a role for replication patterns within antigen presenting cells? Vaccine 16:1473-1478

12. Martinez X, Brandt C, Saddallah F, Tougne C, Barrios C, Wild F, Dougan G, Lambert PH, Siegrist CA 1997 DNA immunization circumvents deficient induction of T helper type 1 and cytotoxic T lymphocyte responses in neonates and during early life. Proc Natl Acad Sci U S A 94:8726-8731

13. Luzuriaga K, Koup RA, Pikora CA, Brettler DB, Sullivan JL 1991 Deficient human immunodeficiency virus type 1 -specific cytotoxic $\mathrm{T}$ cell responses in vertically infected children. J Pediatr 119:230-236

14. Buseyne F, Burgard M, Teglas JP, Bui E, Rouzioux C, Mayaux MJ, Blanche S, Riviere Y 1998 Early HIV-specific cytotoxic T lymphocytes and disease progression in children born to HIV-infected mothers. AIDS Res Hum Retroviruses 14:14351444

15. Spiegel HM, Chandwani R, Sheely ME, Dobroszycki J, Fennelly G, Wiznia A, Radding J, Rigaud M, Pollack H, Borkowsky W, Rosenberg M, Nixon DF 2000 The impact of early initiation of highly active antiretroviral therapy on the human immunodeficiency virus type 1-specific CD8 T cell response in children. J Infect Dis 182:88-95

16. Chiba Y, Higashidate Y, Suga K, Honjo K, Tsutsumi H, Ogra PL 1989 Development of cell-mediated cytotoxic immunity to respiratory syncytial virus in human infants following naturally acquired infection. J Med Virol 28:133-139

17. Khatri VP, Baiocchi RA, Peng R, Oberkircher AR, Dolce JM, Ward PM, Herzig GP, Caligiuri MA 1999 Endogenous $\mathrm{CD}^{+}{ }^{+} \mathrm{T}$ cell expansion during regression of monoclonal EBV-associated posttransplant lymphoproliferative disorder. J Immunol 163:500-506

18. Sester M, Sester U, Gartner B, Heine G, Girndt M, Mueller-Lantzsch N, Meyerhans A, Kohler H 2001 Levels of virus-specific CD4 T cells correlate with cytomegalovirus control and predict virus-induced disease after renal transplantation. Transplantation 71:1287-1294

19. Altman JD, Moss PA, Goulder PJ, Barouch DH, McHeyzer-Williams MG, Bell JI, McMichael AJ, Davis MM 1996 Phenotypic analysis of antigen-specific T lymphocytes. Science 274:94-96

20. Gallimore A, Glithero A, Godkin A, Tissot AC, Pluckthun A, Elliott T, Hengartner H, Zinkernagel R 1998 Induction and exhaustion of lymphocytic choriomeningitis virus-specific cytotoxic $\mathrm{T}$ lymphocytes visualized using soluble tetrameric major histocompatibility class I-peptide complexes. J Exp Med 187:1383-1393

21. Callan MF, Tan L, Annels N, Ogg GS, Wilson JD, O'Callaghan CA, Steven N, McMichael AJ, Rickinson AB 1998 Direct visualization of antigen-specific CD8 ${ }^{+}$T cells during the primary immune response to Epstein-Barr in vivo. J Exp Med 187:1395-1402

22. Rentenaar RJ, Gamadia LE, van DerHoek N, van Diepen FN, Boom R, Weel JF, Wertheim-van Dillen PM, van Lier RA, ten Berge IJ 2000 Development of virusspecific $\mathrm{CD}^{+} \mathrm{T}$ cells during primary cytomegalovirus infection. J Clin Invest 105:541-548

23. Shankar P, Russo M, Harnisch B, Patterson M, Skolnik P, Lieberman J 2000 Impaired function of circulating $\mathrm{HIV}$-specific $\mathrm{CD}^{+} \mathrm{T}$ cells in chronic human immunodeficiency virus infection. Blood 96:3094-3101

24. van Baarle D, Hovenkamp E, Callan MF, Wolthers KC, Kostense S, Tan LC, Niesters HG, Osterhaus AD, McMichael AJ, van Oers MH, Miedema F 2001 Dysfunctional Epstein-Barr virus (EBV)-specific $\mathrm{CD}^{+} \mathrm{T}$ lymphocytes and increased EBV load in 
HIV-1 infected individuals progressing to AIDS-related non-Hodgkin lymphoma. Blood 98:146-155

25. Goulder PJ, Tang Y, Brander C, Betts MR, Altfeld M, Annamalai K, Trocha A, He S, Rosenberg ES, Ogg G, O'Callaghan CA, Kalams SA, McKinney RE Jr, Mayer K, Koup RA, Pelton SI, Burchett SK, McIntosh K, Walker BD 2000 Functionally inert HIV-specific cytotoxic T lymphocytes do not play a major role in chronically infected adults and children. J Exp Med 192:1819-1832

26. Kostense S, Vandenberghe K, Joling J, Van Baarle D, Nanlohy N, Manting E, Miedema F 2002 Persistent numbers of tetramer ${ }^{+} \mathrm{CD}^{+} \mathrm{T}$ cells, but loss of interferon- $\gamma+\mathrm{HIV}$-specific T cells during progression to AIDS. Blood 99:2505-2511
27. Kalams SA, Walker BD 1998 The critical need for CD4 help in maintaining effective cytotoxic T lymphocyte responses. J Exp Med 188:2199-2204

28. Homann D, Teyton L, Oldstone MB 2001 Differential regulation of antiviral T-cell immunity results in stable $\mathrm{CD}^{+}$but declining $\mathrm{CD}^{+}{ }^{+}$T-cell memory. Nat Med 7:913-919

29. Hayward AR, Herberger MJ, Groothuis J, Levin MR 1984 Specific immunity after congenital or neonatal infection with cytomegalovirus or herpes simplex virus. J Immunol 133:2469-2473

30. Pass RF, Dworsky ME, Whittley RJ, August AM, Stagno S, Altford CA Jr 1981 Specific lymphocyte blastogenic responses in children with cytomegalovirus and herpes simplex virus infections acquired early in infancy. Infect Immunol 34:166-170 